\title{
A Study of the Application of Modern Information Technology in Primary School Chinese Teaching
}

\author{
Liu Huan \\ Chinese International Education, Xi'an Shiyou University, Xi'an, China
}

Email address:

18789407845@163.com

To cite this article:

Liu Huan. A Study of the Application of Modern Information Technology in Primary School Chinese Teaching. International Journal of Elementary Education. Vol. 8, No. 3, 2019, pp. 63-67. doi: 10.11648/j.ijeedu.20190803.12

Received: August 30, 2019; Accepted: October 17, 2019; Published: October 23, 2019

\begin{abstract}
With the advent of the internet information age, the application scope of modern information technology is more and more extensive. The deepening of the new curriculum reform in China, the application of modern information technology in Chinese teaching in primary schools is becoming more and more extensive. The application of modern information technology in Chinese teaching in primary schools has greatly improved the flexibility of teaching and the effect of teaching. In the process of Chinese teaching, with the help of modern educational technology, not only can we create situations, stimulate students' interest in learning, create atmosphere, arouse the resonance between students and authors, expand the space and increase the capacity of the classroom, but also create an excellent teaching environment and broaden students' horizons, so as to effectively improve the quality of classroom teaching. However, from the existing researches, it is found that the integration of modern information technology and Chinese teaching in primary schools is still not sufficient. So that modern information technology does not play a real value in Chinese teaching in primary schools. Based on the definition of modern information technology, this study uses literature analysis to explore the application status and application tactics and application advantages. And the author gets enlightenment through exploring. The author hopes that the enlightenment of the study will be helpful for the development of primary school Chinese teaching and guide Chinese educators in primary schools to make better use of modern information technology for Chinese teaching.
\end{abstract}

Keywords: Modern Information Technology, Enlightenment, Primary School Chinese Teaching

\section{Introduction}

The survey report on the current situation of the application of modern information technology in primary school Chinese teaching shows that there are many problems in the application of modern information technology in primary school Chinese teaching, and more attention has been paid to it. By studying the application of modern information technology in primary school Chinese teaching, we can guide the primary school Chinese teachers to be better qualified as "advanced educators" with using modern information technology, and pay attention to the solutions of problems that exist in application of the modern information technology.

\subsection{The Importance of Modern Information Technology in Primary Chinese Teaching}

The application of modern information technology in primary Chinese teaching can better assist teachers in Chinese teaching. Modern information technology can enrich the Chinese teaching methods and teaching resources in primary schools, strengthen the interest of teaching contents, stimulate students' interest in learning and enthusiasm for learning, enhance the interaction and communication between teachers and students, create a relaxed, lively and happy classroom atmosphere, better construct the Chinese teaching classroom in primary schools, and improve the quality and efficiency of classroom teaching. "The application of modern information technology can improve the defects of traditional teaching methods," [8] make the teaching situation more vivid and interesting, and make Chinese teaching keep up with the pace of the times. Of course, in order to meet the requirements of this social development, "the state points out in the newly promulgated curriculum standards that the design and implementation of Chinese curricula in primary schools should attach 
importance to the use of modern information technology, in particular taking fully into account the influence of calculators, computing machines and networks on the content and mode of Chinese learning in primary schools, and vigorously develop and provide students with richer learning resources." [11] Modern educational technology is used as a powerful tool for students to learn primary school Chinese and solve problems, and is committed to changing students' learning style, so that students are willing and have more energy to invest in realistic and exploratory primary school Chinese activities.

\subsection{The Present Situation of Primary Chinese Teaching}

We all know that primary Chinese learning is the basic stage of Chinese learning, is very important. Due to the rich imagination and lively nature of primary school students, the requirements for all aspects of Chinese teaching in primary schools will also be stricter. "The traditional teaching method of "one size fits all" cannot explain the basic knowledge according to the actual situation of students at different levels, and the teaching effect can be imagined." [12] In Chinese classroom teaching activities, teachers blindly explain the central idea of the article, ignore the classroom communication and interaction between teachers and students, and the explanation process takes Chinese teaching materials as the main tool, almost no other teaching tools to assist. Students will lose interest in Chinese classroom learning. The primary Chinese Teaching needs to inject new ways and new teaching concepts to make teaching be interesting and make students better diverge their thinking.

\subsection{The Present Situation of Chinese Teaching Supported by Information Technology}

As an important condition to promote the development of education, information technology is committed to introducing it into education to promote the development of education. However, at present, "as an important part of Chinese language and culture and as a subject with Chinese characteristics, there are few researches on the application of information technology to the teaching of Chinese subjects in foreign countries." [5] The database of CNKI shows that the research of information technology and primary school language accounts for a small proportion, while the application of information technology in primary school language is even less.

\section{Theoretical Basis}

\subsection{The Definition of Modern Information Technology}

There are three different understandings of the definition of modern information technology as described below.

Modern information technology is computer technology; Modern information technology is the integration of computer technology and network technology; "Modern information technology is the integration of audio-visual technology, network technology and integration technology."
[13] The trend of these three explanations is the continuous improvement of information technology. I prefer the third definition of modern information technology. The modern information technology mentioned in this paper also adopts the third view.

\subsection{The Definition of Primary School Chinese Teaching}

Primary school Chinese teaching is the accumulation of emotional attitude, words, words and sentences; First of all, Chinese teaching should let students learn to express, including written expression and oral expression, learn to listen, learn to read, learn to communicate. More importantly, Chinese teaching is to give students a rich emotional world. About the rich emotional world, it means a world that be full of imagination and can be expressed by vivid language.

\section{The Application of Modern Information Technology in Primary Chinese Teaching}

\subsection{Application Status}

There are three points that are worth mentioning. "One is that using information technology excessively; the value of teaching materials is buried. The second point is that the teaching of information technology is mere formality and neglects the "inner beauty" of the teaching content." [1] The last point is that the value of traditional teaching cannot be effectively highlighted when the role is misplaced. About the first point, the author wants to explain carefully. We all know that the wide application of multimedia courseware brings a lot of convenience to teaching. But whether it is for teachers or students to learn, there are drawbacks. For teacher's teaching, some teachers rely too much on multimedia courseware and neglect the experiential activities in the classroom, such as reading and writing. The students' attention is all on the teacher's courseware, and the familiarity with the book is not enough, so it is easy to ignore the importance of textbook.

About the second point, "the application of modern information technology is mere form." [4] Some teachers are with the help of the information technology is still lacking in the process of expanding the material it is appropriate to introduce more factors, such as pictures, videos, and so on, bring the students a dazzled feeling, it's hard to tie up with the contents of the textbook. So that the teaching expands to the surface, it is difficult to make it true the positive connotation and the value are presented. There are many forms of multimedia courseware, which can easily make students lose their creative thinking and be solidified by the courseware that has been done well in advance. "The purpose of Chinese Teaching is to cultivate students' Chinese Literacy." [9] However, the cultivation of Chinese literacy needs teaching contents with important cultural value, rather than a variety of courseware forms.

About the last point, now the study advocates taking the 
student's study as the center, the teacher's teaching as the leading, the teacher guides the student to learn in the classroom, the student is the main body of the classroom. But teachers overuse multimedia courseware, resulting in the role of teachers and students are misplaced, classroom teaching has become a teacher singing monologue, student's passive input without output. The interaction between teachers and students in traditional teaching, the interaction between students and students gradually disappears, and the teaching value is limited.

The reasons for application status of primary school Chinese teaching are as follows. There are many reasons for these problems. Here the author will discuss them from two aspects: objective factors and subjective factors.

About the objective factors, also have two aspects: "one is that the requirements for the use of multimedia courseware in schools are too formalized, the other is that lack of professional training in information technology in schools." [14]

Firstly, multimedia courseware is often used in schools, but teachers seldom use multimedia courseware, but they use it more often in open classes, and the heavy teaching task also makes it impossible for teachers to prepare the courseware.

Secondly, lack of professional training in information technology in schools. Schools attach importance to the cultivation of teachers' teaching ability, but the teaching ability focuses on professional knowledge and teaching methods, neglecting the systematic cultivation of modern information technology. In the internet era, it is difficult for teachers to educate modern information through their own ability.

About subjective factors, it has two points. First of all teachers do not have the enough understanding of teaching under information technology. "Some Chinese teachers cannot control the use of information technology in teaching," [6] rely on information technology in the classroom, and ignore the auxiliary function of information technology. The second point is that many Chinese teachers have heavy teaching tasks, do not have enough time to use modern information technology in the classroom, and do not have enough time to do multimedia courseware, and so on. Next, the author would like to talk about the application advantages of modern information technology in Chinese teaching in primary schools

\subsection{Application Advantages}

First of all, from the perspective of teaching rules, modern information technology can make the teaching content be information and digitization, and use diversified ways to present these contents to the students, strengthen students' understanding and absorption of all kinds of knowledge, and improve the effect of classroom teaching. "We know that so many students think Chinese language is difficult, but we cannot find out the specific reasons. Chinese teaching is abstract, and modern information technology can help us materialize." [10] Secondly, from the point of view of teaching mode, modern information technology can make students and teachers break through the imitations of time and space, and provide a broad communication and interaction platform for teachers and students. Teachers and students no longer limit their thinking to the text, but broaden their minds and develop rich associations. Furthermore, from the point of view of teaching content, the classroom teaching under the modern information technology is no longer limited to the knowledge content in the textbook, which expands the students' knowledge and enables them to better understand and master the teaching knowledge points. Finally, from the point of view of teaching methods, modern information technology has greatly expanded the means of classroom teaching, fully integrated the internet and information technology into teaching, and improved the effectiveness of teaching. The second point is that many Chinese teachers have heavy teaching tasks, do not have enough time to use modern information technology in the classroom, and do not have enough time to do multimedia courseware, and so on.

\subsection{Application Tactics}

In view of the present situation of the application of modern information technology in Chinese teaching in primary schools, there are several effective application strategies. Firstly, using modern information technology to create vivid Chinese teaching situation and arouse students' enthusiasm for learning. "In the process of Chinese teaching in primary schools, teachers should use multimedia technology to create relevant classroom situations according to different teaching contents, vividly display the content of teaching materials, and then touch students' hearts and cultivate students' Chinese literacy."[15] Teachers use multimedia equipment to excavate interesting and artistic content in Chinese teaching materials, which can fully stimulate students' interest in learning and enthusiasm for learning, stimulate students' vision and hearing through pictures, audio-visual, text, video, music, animation and other ways, bring students into a good teaching situation, further attract the attention of students, and strengthen students' curiosity and thirst for knowledge in the content of teaching materials. This can arouse the enthusiasm of students to participate in teaching activities, and to really become the master of learning. It also can better realize the student's study as the center, the teacher's teaching as the guide. "Chinese teachers in primary schools should keep abreast of the times and innovate and apply modern information technology." [3] So that modern information technology can better serve the teaching of Chinese literacy and writing, reading teaching, practice teaching and oral communication teaching in primary schools.

Secondly, it is an important goal of primary school language teaching to improve students' Chinese literacy and cultivate pupils' Chinese literacy by using modern multimedia technology to optimize the Chinese classroom teaching environment of primary school students. Especially for students, as a subject of Chinese, "the quality of Chinese 
learning has a direct impact on the learning of other subjects." [2] Therefore, educators must attach importance to the position of Chinese subject, under the guidance of the new curriculum concept, scientifically use modern information technology to optimize and integrate teaching resources, display them in front of students in an appropriate form, enhance the interest, vividness and intuition of teaching, deepen students' understanding and understanding through fresh teaching resources, deeply understand the content of teaching materials, and master teaching knowledge. These all can help improve understanding ability and appreciation ability and improve Chinese subject literacy.

Thirdly, using modern information technology to optimize teaching methods and learning methods in the traditional Chinese teaching mode of "cramming" and "infusion" teaching methods, teachers as the main body of teaching activities, students passively accept knowledge, classroom teaching effect is not ideal. "The new curriculum reform emphasizes the learning style of autonomy, cooperation and discussion." [2] This concept repositions the students' main position in Chinese teaching activities, and makes students change from passively accepting knowledge to actively exploring knowledge, and the teaching style is greatly innovated. By using modern information technology, students can study selectively according to their own actual situation, which cannot be digested and absorbed in the classroom, and can learn independently by watching courseware over and over again after class, and gradually form good learning habits. "Information technology can be used as the main way of collection of teaching data." [7] At the same time, the use of network teaching platform can realize the learning communication and interaction between teachers and students, which is helpful to cultivate students' spirit of group cooperation.

\section{Enlightenment}

\subsection{Enlightenment to Primary Language Teacher}

From the studying of the application of modern information technology in primary school Chinese teaching, the author gives primary language teacher some enlightenment about using modern information technology to teach. Primary language teacher can teach students better and better through studying enlightenment. First of all, Primary language teacher should change educational view of thinking that information technology can only be a simple tool for presenting the content of textbooks. They should have a right view of using modern information technology in teaching and understand modern information technology should be used to solve the difficulties and key points in teaching content. Secondly, strengthening the ability of teachers to control the classroom of using modern information technology and this requires teachers to constantly improve their abilities in all aspects and control the relationship between students' classroom attention and multimedia courseware.

\subsection{Enlightenment to Relevant Education Departments}

It is the inevitable trend of the development of the times for modern information technology to enter the classroom. However, due to the uneven distribution of educational resources, many areas with backward education do not have the hardware equipment to use modern information technology. Therefore, this requires the relevant education departments to pay attention to this issue and increase investment in education in remote areas. What's more, some old teachers cannot accept the view of using modern information technology in class, this also requires the relevant education departments to increase the dissemination of information concept, so that some teachers change the traditional concept and keep pace with the times. The author hopes this enlightenment can be useful.

\section{Conclusion}

Through the author's study, it is not hard to draw a conclusion that application of modern information technology in primary school Chinese teaching is constantly improving and will be more and more perfect. The author finds out the application from three aspects and these applications have great meaning for primary Chinese teaching. As a person who will become a Chinese teacher in the future, the author knows that the importance of the application of modern information technology in Chinese teaching in primary schools. The educational views of using modern information technology in class needs to be improved. Educational method should be reformed. In fact, a country's economy determines the direction of education and determines the method of education. Of course, with the continuous development of information age, the importance of modern information technology to teaching will become more and more prominent. The author hopes that more and more primary school Chinese teachers can correctly deal with the application of modern information technology in teaching and use information technology to promote Chinese education in primary schools.

\section{Acknowledgements}

First of all, my deepest gratitude goes to Professor Zhang, my supervisor, for his constant encouragement and guidance. Under his careful guidance, I learn to change the title of my thesis from broad to appropriate and I learn to write the right outline by using the information that I collected. When I was writing a paper, I had problems that I could not solve; Professor Zhang was always patient in giving me guidance. And Professor Zhang recommended me to publish my paper actively.

Besides, I want to express my sincere thanks to my dear Professor Zhang who help me find out the way to look for documents. He is a person who likes to do academic research, so he is good at finding all kinds of information. 


\section{References}

[1] Bai, K. (2018). An Analysis of the present situation of the application of information technology in primary school Chinese. Read and Write Periodical, 3 (15), 117-118.

[2] Chen, H. (2017). Research on the effective application strategy of information technology in primary school Chinese. Chinese Educational Technology, (19), 20-21.

[3] Dai, Y. (2018). How to use modern information technology in Chinese teaching in primary schools. Media Culture, (31), 74-76.

[4] Huang, L. (2019). Research on the expansion of Chinese classroom teaching in primary school under the environment of information technology. Teacher's Journal, 79-80.

[5] Huang, X. (2019). Research on class teaching interactive behavior under support of information technology-take the Chinese class in primary schools as an example. Shenyang Normal University, 1-10.

[6] Ji, N. (2017). Research on the application of multimedia courseware in Chinese teaching in primary school. Shandong Normal University, 30-32.

[7] Tan, R. (2018). How to better apply information technology to Chinese teaching in primary schools. Curriculum and Teaching, 18(54), 78-79.

[8] Wei, X. (2018). On the application of information technology in Chinese teaching. Information Technology and Teaching, (10), 186-187.

[9] Wang, Z. (2018). The integration of modern information technology and Chinese classroom teaching in primary schools. Science and Technology Education, (11), 170-172.

[10] Wang, Y. (2007). The research about combing modern information technology with primary language course. Northwest Normal University, 42-47.

[11] $\mathrm{Xu}, \mathrm{W}$. (2018). Using modern information technology to optimize Chinese teaching in primary schools. Chinese Out-of-school Education, (02), 165-166.

[12] Yang, J. (2018). Analysis on the application strategy of information technology in primary school Chinese. Read and Write Periodical, 4 (15), 158-159.

[13] Yao, C. (2018). Research on Chinese teaching based on information technology. Technology and Economic Guide, 6 (15), 170-171.

[14] Zhou, T. (2017). The application of micro-course in Chinese teaching. Chinese Out-of-school Education, (11), 53-60.

[15] Zhen, X. (2018). Research on Chinese teaching strategies in the era of media integration. Teaching and Management, (31), $79-82$. 